\title{
Maladministration in Land Dispute Resolution Services in the Lampung Provincial National Land Agency
}

\author{
Shandi Patria Airlangga ${ }^{1}$, HS Tisnanta ${ }^{2}$, FX Sumarja ${ }^{3}$ \\ \{patriashandi@gmail.com ${ }^{1}$, s.nymus@yahoo.co.id ${ }^{2}$, fxsmj.unila@gmail.com ${ }^{3}$ \} \\ Faculty of Law University Lampung, Indonesia
}

\begin{abstract}
Land dispute as a crucial problem in Indonesia, where handling is still less effective and efficient. This argument is based on the results of a systemic study "Potential Maladministration in Services for Settling Land Disputes and Blocking Land at the Land Office in Lampung Province" by the Team of Lampung Pro-Province Ombudsman Study on 7 (seven) Land Offices in Lampung Province in 2018. There were indications of maladministration in the flow of land dispute resolution at the Lampung Province National Land Agency (BPN). The indications of maladministration are a reflection of the quality of BPN services. To test the BPN bureaucracy, bureaucratic development models are used and recommend effective and efficient service solutions. This study is a normative juridical legal research, and the problem approach used are legislation approach and conceptual approach. Secondary data used were the results of a systemic study by the Lampung Province Ombudsman team and other legal materials. Data analysis used is quantitative data analysis. The results of the study show that the causes of maladministration are caused by a lack of competencies in human resources and various obstacles. The BPN bureaucracy is also classified as Pre-Bureaucratic because there is still a flow of dispute resolution that is not following the Minister of Agrarian Regulation and Spatial Planning No. 11 of 2016 concerning Land Settlement. BPN needs to improve the quality of its bureaucratic structure to provide effective and efficient dispute resolution services.
\end{abstract}

Keywords: Maladministration; Land Dispute Resolution Service

\section{Introduction}

Land disputes is a popular problem in Indonesia, which is currently less effective and efficient. This argument departs from the results of a systemic study of "Potential Maladministration in Services for Settling Land Disputes and Blocking Land at the Land Office in Lampung Province" by the Team of Lampung Pro-Province Ombudsman Study on 7 (seven) Land Offices in Lampung Province in 2018. Based on these data, indications of maladministration were found in the flow of land dispute resolution at the Lampung Province BPN. The indications of maladministration are a reflection of the quality of land dispute resolution services at the BPN. To test the hypothesis, used bureaucratic development model from Philippe Nonet and recommended effective and efficient service solutions. 
Based on this background, the problems are:

1. Why is there maladministration in resolving land disputes at the BPN?

2. How does the BPN bureaucracy test results use the bureaucratic development model?

\section{Methods}

The method used is normative juridical, problem approach used is legislation approach and conceptual approach. Secondary data used are the results of systemic studies by the Ombudsman Representative Team of Lampung Province. Data analysis using qualitative data analysis. Data processing is carried out with inventorying data, systematizing interconnected data, interpreting data theoretically and authoring legal arguments, analyzing the data accordingly to answer existing problems. The legal theory used departs from Responsive Legal Theory. Philippe Nonet and Philip Selznick introduced 3 (three) types of bureaucracy as evolutionary forms of continuity; those are bureaucratic, bureaucratic, and post-bureaucratic as manifestations of the evolution of legal types of a repressive law, autonomous law, and responsive law.

\section{Results and Discussion}

\subsection{Causes of Maladministration in Land Dispute Resolution Service at BPN}

The causes of maladministration in this paper are traced using the diachronic method, which is a method to find the truth by tracing period. With this method, the author divides the time of occurrence of maladministration into 2 (two) periods, which includes:

1. Maladministration on land registration for the first time; and

2. Maladministration on land dispute resolution services.

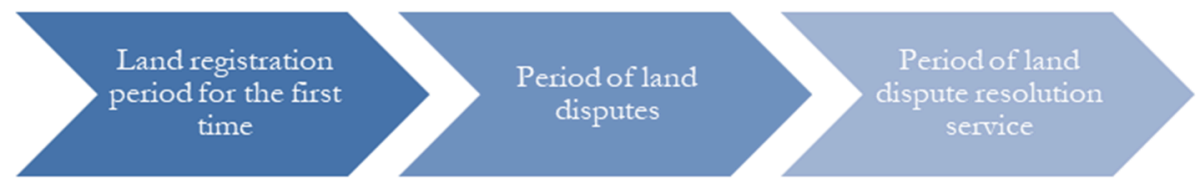

Fig 1. The Periodization of Maladministration in Settling Land Disputes

\section{Maladministration on Land Registration for the First Time}

Based on research data in 7 (seven) Land Offices in Lampung Province, there were no indications of maladministration in the substance aspect, because there were no errors or errors in the physical data and land juridical data. However, based on the author's hypothesis, maladministration can occur in land registration for the first time, those are on:

1. Registration of Basic Maps: Measurement and mapping for the making of basic registration maps are carried out by terrestrial, photogrammetric and other methods. Terrestrial methods are carried out on the surface of the earth, while photogrammetric methods are carried out in the air. While other methods can be done, but in Article 12 paragraph (1) Minister of Agrarian Regulation and Spatial Planning No. 3 of 1997 concerning Implementation Provisions of Government Regulation No. 24 of 1997 concerning Land Registration, do not mention other methods that are allowed. To avoid errors in measurement and mapping, the phrases in the rule should be emphasized. 
2. Determination of Land Sector Limits: Physical data for land registration is obtained by measuring the land parcels to be mapped, its location, boundary, and boundary signs placed at the corners of the land. In the case of stipulating land parcels on land registration, boundary arrangements are based on the agreement of the parties. If there is no agreement, but it is still carried out without the knowledge of the parties, this can lead to errors in setting boundaries in the plots of land, resulting in maladministration caused by the neglect of obligations and neglect of the law.

3. Measurement and Mapping of Land Plots and Making a Registration Map: Plots of land that have been determined are measured and mapped in the registration base map. Making this registration map is sensitive, so it requires the competency of the officer responsible for carrying it out. Maladministration actions that are prone to occur in this plot are incompetence in measuring and mapping land parcels that cause errors in physical data.

4. Land Register Making: Land parcels that have been mapped on the registration map, are recorded in the land register. Need accuracy and thoroughness of the responsible officer and carried out according to AUPB so that there is no mistake in affixing the registration number in the registration and bookkeeping map in the land register which results in maladministration.

5. Preparation of Measuring Letters: For land parcels that have been measured and mapped on the registration map, a measured letter is made for registration of their rights. In the letter of measurement can be seen the location of the land, the area of land, and whoever the measuring limit is. The physical data must be by the conditions in the field so that there is no discrepancy or in other words, maladministration.

\section{Maladministration in Land Dispute Resolution Service at BPN}

Based on the existing secondary data, maladministration in 7 (seven) Land Offices in Lampung Province is indicated as a maladministration action. Maladministration that occurs in the flow of land dispute resolution services in BPN Lampung Province, among others :

1. Complaint Check: There is 1 (one) Land Office providing a Receipt of Complaint to the complainant if the complaint file is declared to meet the requirements, while there are 6 (six) Land Offices not giving a Receipt of Complaint to the complainant if the complaint file is declared to have met the requirements. Administrations that occur include:

a. Disregard of law: Whereas in Article 7 paragraph (3) of the Minister of Agrarian Regulation and Spatial Planning No. 11 of 2016 concerning Land Settlement, complaints that have met the requirements, to the complainant are given a Receipt of Complaints;

b. Deviation of procedures: Caused by incomprehension and incompetence, due to a lack of improvement in human resource capabilities, in this case, an increase in legal knowledge.

2. Recording/Administration of Development of Dispute Settlement: There are 5 (five) Land Offices recording the progress of disputes in the Dispute Resolution Register and administering through the Dispute Information System, while there are 2 (two) Land Offices recording the progress of disputes in the Dispute Resolution Register and not administering through the Dispute Information System. Administrations that occur include:

a. Disregard of law: Whereas in Article 9 paragraph (1) of the Whereas in Article 9 paragraph (1) Minister of Agrarian Regulation and Spatial Planning No. 11 of 2016 concerning Land Settlement, every development of dispute resolution, data administration is carried out through the Dispute Information System; 
b. Deviation of procedures: That the official responsible for handling disputes should explain that any progress in dispute resolution is administered through the Dispute Information System.

3. Data Collection: There are 5 (five) Land Offices conducting data collection in the dispute resolution stage, while there are 2 (two) Land Offices not explaining data collection in land dispute resolution. Administrations that occur include:

a. Disregard of law: Whereas in Article 10 of the Permen on Settlement of Land Cases, data collection is carried out so that officials responsible for handling disputes cannot conduct analysis;

b. Deviation of procedures: That with no explanation of data collection, a procedure deviation has occurred which has resulted in data analysis not being carried out;

4. Analysis: There are 2 (two) Land Offices explaining the implementation of the analysis of land dispute resolution, while there are 5 (five) Land Offices not explaining the analysis of land dispute resolution, so it is not known that the complaint is the authority of the ministry or not the authority of the Ministry. Administrations that occur include:

a. Disregard of law: Whereas in Article 11 of the Minister of Agrarian Regulation and Spatial Planning No. 11 of 2016 concerning Land Settlement, carried out the analysis, so it is not known that the complaint is the authority of the ministry or not the authority of the ministry;

b. Deviation of procedures: That by not explaining the analysis, there has been a procedure deviation which has resulted in the dispute being unknown as the authority of the ministry or not the authority of the ministry;

5. Dispute Resolution: There are 7 (seven) Land Offices in Lampung Province explaining that dispute resolution, which is the authority of the Ministry is carried out through mediation. The results of data collection and analysis are not reported to the Head of the Land Office so that the Head of the Land Office does not submit the results of data collection and analysis to the Head of the BPN Regional Office or to the Minister to follow up the settlement process. Administrations that occur include:

a. Disregard of law: Whereas in Article 6-27 of the Minister of Agrarian Regulation and Spatial Planning No. 11 of 2016 concerning Land Settlement, dispute resolution which is the authority of the ministry, is resolved through the appropriate stages, not through mediation. That is Article 12 paragraph (1) the official responsible for handling disputes, reports the results of data collection and analysis to the Head of the Land Office, then in Article 13 paragraph (1), The Head of the Land Office shall convey the results of data collection and analysis to the Head of the Regional Office of the Land and the Minister;

b. Dishonesty: That the official responsible for handling dishonest disputes or hiding an explanation of the data analysis in settlement of land disputes. That the results of data collection and analysis should be reported to the Head of the Land Office;

6. Mediation: There are 4 (four) Land Offices which explain that dispute resolution that is not the authority of the Ministry can be made through mediation, while there are 3 (three) Land Offices which do not explain that mediation can be done in resolving disputes which are not the authority of the ministry. Administrations that occur include:

a. Disregard of law: Whereas in Article 37-42 of the Article 6-27 of the Minister of Agrarian Regulation and Spatial Planning No. 11 of 2016 concerning Land Settlement , dispute resolution which is not the authority of the ministry, is resolved through mediation based on the agreement of the parties. This means that there has been maladministration related to the neglect of the law, which has resulted in an 
unknown settlement of the option of dispute resolution through mediation facilitated by the BPN.

b. Favoritism in interpreting the law: That an official responsible for handling disputes interprets the law for certain interests, the official responsible for handling disputes should explain that mediation can be done in resolving disputes that are not the authority of the ministry.

\subsection{Development Model of BPN Bureaucracy}

The bureaucratic development model is a theory of institutional limitations and responses whose function is to identify the evolutionary level of bureaucracy. In this theory, there are 3 (three) developments in the bureaucracy, which include:

1. Pre-Bureaucratic: identical to the bureaucratic system that is still old-fashioned or has not implemented bureaucratic elements determined by legislation;

2. Bureaucratic: synonymous with the bureaucracy that meets standards, but its nature is still rigid and fettered by rigid rules, in other words not progressive;

3. Post Bureaucratic: synonymous with modern bureaucracy, and meets bureaucratic elements that meet regulatory standards and has progressive initiatives in carrying out its functions.

Philippe Nonet and Philip Selznick interpreted 3 (three) types of bureaucracy as evolutionary forms, including pre-bureaucratic, bureaucratic and post-bureaucratic. This model illustrates of legal types of a repressive law, autonomous law and responsive law. The function of this bureaucratic development model is to determine the level or condition of the bureaucracy of an organ, in this case, the organ of government, to find the root of the problem in a bureaucracy.

Table 1. Three Types of Formal Organizations

\begin{tabular}{|c|c|c|c|}
\hline & PREBUREAUCRATIC & BUREAUCRATIC & POSTBUREAUCRATIC \\
\hline PURPOSE & $\begin{array}{l}\text { Particularistic; confusion } \\
\text { of private interests and } \\
\text { public responsibilities }\end{array}$ & $\begin{array}{l}\text { Explicit, fixed, public; } \\
\text { identified by assigned } \\
\text { jurisdiction }\end{array}$ & Mission-oriented; flexible \\
\hline AUTHORITY & $\begin{array}{l}\text { Traditional, charismatic, } \\
\text { unstructured }\end{array}$ & $\begin{array}{l}\text { Hierarchically subdivided } \\
\text { spheres of competence; } \\
\text { communication "through } \\
\text { channels"; formal rationality }\end{array}$ & $\begin{array}{l}\text { Team and task force } \\
\text { organization; open } \\
\text { communication; diffusion } \\
\text { of authority; substantive } \\
\text { rationality }\end{array}$ \\
\hline RULES & Unsystematic & $\begin{array}{l}\text { Codified; blueprints for } \\
\text { action; focus on administrative } \\
\text { regularity }\end{array}$ & $\begin{array}{l}\text { Subordinated to purpose, } \\
\text { avoidance of rule- } \\
\text { boundedness }\end{array}$ \\
\hline $\begin{array}{l}\text { DECISION } \\
\text { MAKING }\end{array}$ & $\begin{array}{l}\text { Ad hoc; concrete rules } \\
\text { and subordinates who do } \\
\text { not comply }\end{array}$ & $\begin{array}{l}\text { Systematic; routinised; limited } \\
\text { delegation; controlled } \\
\text { conditions and subordinates } \\
\text { who obey the rules }\end{array}$ & $\begin{array}{l}\text { Participatory; problem- } \\
\text { centered; broad delegation; } \\
\text { assumption of the } \\
\text { environment of shifting } \\
\text { requirements and } \\
\text { opportunities }\end{array}$ \\
\hline CAREERS & $\begin{array}{l}\text { Uncontrolled conditions, } \\
\text { do not work well; efforts } \\
\text { to benefit the elite }\end{array}$ & $\begin{array}{l}\text { Work well, contribute; free } \\
\text { from personal interests; based } \\
\text { on work results; emphasis } \\
\text { on seniority and tenure }\end{array}$ & $\begin{array}{l}\text { More than one affiliate and } \\
\text { is temporary; cooperate } \\
\text { with sub-contracts if } \\
\text { needed; } \\
\text { work with professional } \\
\text { abilities }\end{array}$ \\
\hline
\end{tabular}


The following is a discussion of data on the dispute resolution service flow indicated by maladministration in 7 (seven) Land Offices in Lampung Province which were tested using a bureaucratic development model theory with the following 5 (five) aspects:

1. Examination of complaints file: there is an obligation to provide a Receipt of Complaints if the complaint does not meet the requirements, then notify them in writing;

2. Recording/Administration of Development of Dispute Settlement: there is an obligation to record the progress of dispute resolution in the Register for Settling Disputes and administering it through the Dispute Information System;

3. Data collection: there is an obligation to collect data in the stages of dispute resolution;

4. Implementation of analysis: there is an obligation to explain the implementation of the analysis in dispute resolution;

5. Dispute resolution: there is an obligation to explain that dispute resolution that is not the authority of the Ministry is carried out through mediation.

Based on the flow, the results of analysts using the bureaucratic development model are as follows:

1. Purpose:

a. Pre-bureaucratic services are 25 (twenty-five) services because they do not fulfil explicit, definite, public, and identified elements with defined jurisdiction;

b. Services are classified as bureaucratic in the number of 17 (seventeen) services, because they fulfil explicit, definite, public, and identified elements with defined jurisdiction;

c. Services are classified as Bureaucratic Post at 0 (zero) services because they don't fulfil flexible mission-oriented elements.

2. Authority:

a. Pre-bureaucratic services are 25 (twenty-five) services because they do not fulfil structured and communication elements through channels, and fulfil traditional elements;

b. Services are classified as bureaucratic in 1 (one) service because they fulfil structured and communication elements through channels;

c. Ministry is classified as a bureaucratic post with 16 (sixteen) services because it fulfils the elements of the task of open communication, diffusion of authority, team and group organizations, and open communication tasks.

3. Rules:

a. Pre-bureaucratic services are 25 (twenty-five) services, because they do not fulfil the element of focus on administrative order and blueprints for action, and fulfil non-systematic elements;

b. Service is classified as bureaucratic by 17 (seventeen) services because it fulfils the element of focus on administrative order and blueprint for action;

c. Services are classified as Post-Bureaucratic in the amount of 0 (zero) services because they do not fulfil the Subordinate element towards the purpose of rejecting the attachment to regulations.

4. Decision Making:

a. Pre-bureaucratic services are 25 (twenty-five) services because they do not fulfil routine elements, are obedient to rules, systematic, and fulfil the elements of uncontrolled actions carried out by subordinates; 
b. Services are classified as bureaucratic in the amount of 10 (ten) services because they fulfil routine elements, are obedient to rules, and systematic;

c. Service is classified as a bureaucratic post with 7 (seven) services because it fulfils the element of participatory, problem-centered, broad delegation, and tone of assumptions about the environment with changing demands and opportunities.

5. Careers:

a. Pre-bureaucratic services are 25 (twenty-five) services because they do not fulfil the element of professionalism;

b. Services are classified as bureaucratic in the amount of 5 (five) services because they fulfil the element of professionalism;

c. The service is classified as a bureaucratic post with 12 (twelve) services because it fulfils the element of affiliation, and experts have an autonomous professional foundation.

Results of Flow Analysis of Land Dispute Resolution Services in 7 (Seven) Land Offices in Lampung Province Using the Development Model of Bureaucracy

$\square$ Pre-Bureaucratic Service $\square$ Bureaucratic Service

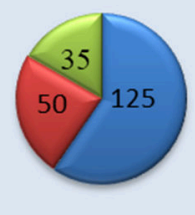
$\square$ Post Bureaucratic Service

Fig 2. Results of Flow Analysis of Land Dispute Resolution Services

This figure is a reflection of the quality of land dispute resolution services at the BPN. It can be concluded that the BPN is still in the pre-bureaucratic development model with 125 pre-bureaucratic services. Nevertheless, in practice, BPN continues to carry out its duties and functions optimally. The level of BPN services can also be seen in the Community Satisfaction Index (IKM) on the ATR/BPN Ministry website. The elements assessed in the IKM include procedures, requirements, fairness, costs, security, the certainty of costs and time of completion, etc.

\section{Conclusion and Recommendation}

Most of the indications of maladministration are the ignore of obligations and ignore the law. For this reason, the solution that the writer can recommend is to improve the employee acceptance system, reduce excessive work pressure on employees, provide training to improve employee skills, place employee positions according to their scientific background. Regarding legal knowledge, employees should be given legal socialization by presenting competent speakers, recruiting employees who are experts in the field of land law, cooperating with competent stakeholders, improving the flow of dispute resolution that is not by the legislation to be adjusted.

The Pre-Bureaucratic development model counts 125 services; in other words, around $60 \%$ of the flow is indicated as maladministration, while the other $40 \%$ do not occur in maladministration. Thus it is also known that BPN is still in the model of Pre-Bureaucratic 
development. BPN should optimize its bureaucracy to avoid maladministration and provide effective and efficient services.

\section{References}

[1] Caiden, Gerald E. (2017). "Maladministration Revisited", International Journal of Civil Service Reform and Practice Vol 2, No 1 (2017). Astana: Astana Civil Service Hub. pp. 3-4.

[2] Hadjon, Philipus M. (1993). Pengantar Hukum Administrasi Indonesia. Yogyakarta: Gadjah Mada University Press.

[3] Marzuki, Peter Mahmud. (2005). Penelitian Hukum. Jakarta: Kencana.

Nonet, Philippe and Philip Selznick. (2017). Toward Responsive Law: Law and Society in Transition. New York: Routledge.

[4] Nurtjahjo, Hendra. (2013). Memahami Maladministrasi. Jakarta: Ombudsman Republik Indonesia.

[5] Sampara, Said. (2014). "Maladministration in The Context of The Public Service", Journal of Humanity Vol. 2, No. 1, July. 2014. Sulawesi: Universitas Sulawesi Barat. pp. 113-120

[6] Sumarja, FX. (2009). Hukum Pendaftaran Tanah, Lampung: University of Lampung.

[7] Suryadi, Andi. (2018). "Berpikir Kronologis, Sinkronik, Diakronik, Ruang dan Waktu dalam Sejarah", Deepening of Indonesian History Material PPG in Position, Kemenristekdikti. p. 10.

[8] Wheare, K. C. (1973). Maladministration and Its Remedies. London: Stevens and Sons. pp. 34.

[9] Yusuf, Nur Rahman, et al. (2018). "Potensi Maladministrasi dalam Pelayanan Penyelesaian Sengketa Tanah dan Blokir Tanah pada Kantor Pertanahan di Provinsi Lampung". Lampung: Lampung Provisional Ombudsman Study Team. pp. 62-77.

[10] Minister of Agrarian and Spatial Planning/Head of BPN Regulation No. 3 of 1997 concerning Implementation Provisions of Government Regulation No. 24 of 1997 concerning Land Registration.

[11] Minister of Administrative Reform and Bureaucratic Reform Regulation Number 16 of 2014 concerning Guidelines for the Community Satisfaction Survey on the Implementation of Public Services.

[12] Minister of Agrarian and Spatial Planning/Head of BPN Regulation No. 11 of 2016 concerning Land Settlement. 